\title{
The Essential Role Of Renewable Energy In A Sustainable Future
}

Patricia T. Papachristou, (E-mail: ppapachr@cbu.edu), Christian Brothers University Gerald C. Papachristou, University of Memphis

\begin{abstract}
This paper examines why renewable energy is essential to building a healthy, reliable, and secure future, that ultimately, will be both more cost efficient and beneficial to the environment. Despite the reluctance of the American national government to commit itself to renewable energy, several countries and California are demonstrating how renewable energy can become a significant part of their economy in less than a decade. While private corporations are important, government incentives and disincentives play a decisive role in the successful conversion to renewables.
\end{abstract}

\section{INTRODUCTION}

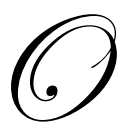

nly with an emphasis on renewable energy will the United States be able to look confidently to a future that is more healthy, more secure, and more economically viable. Unfortunately, our national leaders are looking backward, relying on old, coal-burning or potentially dangerous, nuclear technology to fulfill our future energy needs. By turning around and embracing new, proven technologies used widely throughout the world, we can take advantage of energy sources that are non-polluting, decentralized and easily available.

Recent technological breakthroughs have made wind and solar energy excellent economic investments which will lessen our reliance on energy based on burning fossil fuels. We can no longer look the other way as Denmark, Germany, Spain, China and our own California, commit themselves to reduce drastically carbon and other pollutants, using economic incentives and clean energy. Energy conservation by citizens and the emphasis on standards of energy efficiency in building codes, refrigerators, furnaces, and lighting, all help to lower the use of energy by the population. California also gives rebates (up to \$2000) to homeowners for solar and wind energy installations, but only if their homes "beat building standards for energy efficiency". As a result, Californians have been able to reduce their average use of energy per year to 7,000 kilowatt hours (KW) per household, compared to 12,000 KW hours for the average American (Mufson, 20).

Despite California's success, 150 coal-fired plants across the country are planned, according to the National Energy Technology Laboratory, as of February 2007. Most of them will be using the old technology of pulverized coal rather than the less polluting technology called Integrated Gasification Combined cycle (IGCC) (VelasquezManoff,16) Tennessee Valley Authority (TVA) announced on May 7, 2007 that it was starting up its Browns Ferry Nuclear Plant after a five year restoration effort. It was shut down ("idled") in the 1980's (Mansfield). While coal is a relatively cheap form of energy, if obtained locally, its pollutants are harmful to the environment and to the population nearby. They also contribute to global warming and become a health hazard far down wind of the plant. Our reliance on imported oil for over 60 percent of our annual needs makes us heavily dependent on unstable oil producing nations and the necessity to protect our overseas oil supplies in order to protect our national security. In contrast, embracing renewable energy, will make us less dependent and make more of our energy mix decentralized in our own country. As renewable energy is substituted for fossil fuel, the production of green house gases (GHG) will be reduced. Consequently, it will be easier to avert the dangers of global warming. 


\section{THE PROBLEM OF GLOBAL WARMING}

Global warming illustrates the challenge of sustainable development by highlighting inter-generational equity issues. Continuing our reliance on fossil fuels to power our economy without regard to their environmental impact will doom future generations in less than a hundred years. Although the effects of burning fossil fuels is showing up in higher concentration levels of carbon in the atmosphere, its consequences are only now being seen by experts on climate change. In the ground breaking book, Eco-Economy: Building an Economy for the Earth (2001), Lester R. Brown details the problems arising from an economic accounting of Gross Domestic Product (GDP) that does not take into consideration the full environmental costs and health consequences of relying on fossil fuels to power the world economy. According to Brown,

With the huge growth in burning of fossil fuels since 1950, carbon emissions have overwhelmed the capacity of the eco-system to fix carbon dioxide. The resulting rise in atmospheric CO2 levels is widely believed by atmospheric scientists to be responsible for the earth's rising temperatures. The 14 warmest years since record-keeping began in 1866 have all occurred since 1980. $(2001,12)$

Brown discusses the effects of rising temperatures on ice melting, causing the sea-level to rise and endanger the port cities around the world. He shows how rising temperatures and the more destructive power of storms are related. In his new book, Plan B: Rescuing a Planet under Stress and a Civilization in Trouble, Brown describes these effects in detail. The relationship between rising temperatures and declines in food production is examined. Higher temperatures reduce output by slowing down the process of photosynthesis. At temperatures over 104 degrees Fahrenheit, photosynthesis stops entirely (Brown 2003,63). Consequently, the rising temperatures and falling water tables are a danger to our food security. Grain output has declined substantially over the last decade.

At the beginning of the industrial age in 1760, carbon levels in the atmosphere were estimated at 280 parts per million (ppm). In 1960 they rose to $316 \mathrm{ppm}$. Since then they have climbed to $373 \mathrm{ppm}$. Carbon concentrations in the atmosphere have a life of over 100 years, so just cutting emissions will not solve the problem. The United Nations Intergovernmental Panel on Climate Change (IPCC) has concluded that global warming is caused from too much carbon dioxide being emitted into the atmosphere. The IPCC previously projected an increase in average global temperatures of 3 to 7 degrees Fahrenheit this century. In 2001, the IPCC raised its upper estimate to 10.4 degrees. According to Tom Wigley, a member of the UN's IPCC, to keep temperatures from rising more than a few degrees requires a stabilization of atmospheric concentrations of green house gases (Blowing hot...). The Kyoto Protocol requires that signatories cut back their emissions of carbon dioxide by 5 percent. This can only be seen as a first step.

In order to slow global warming, the market must tell the ecological truth of how detrimental carbon emissions have become for public health and the environment. Yet, burning fossil fuels to generate electricity causes over a third of the greenhouse gas emissions, as well as two-thirds of the emissions that cause acid rain, and onethird of the emissions that cause smog (AWEA, 2007). Reducing subsidies for fossil fuels and increasing incentives to renewable energies, as the Danes have done, could dramatically reduce the use of fossil fuels and cut GHG emissions in the United States. Elsewhere, Belgium, France and Japan have removed all subsidies for coal. After Germany lowered its coal subsidy from $\$ 5.4$ billion in 1989 to $\$ 2.8$ billion in 2002, its use of coal fell by 46 per cent. Unlike countries in the European Union that have seen a drop in GHG emissions in the nineties, the United States has experienced a 16 percent increase in our emissions which contribute to global warming.

The price of fossil fuels does not reflect its full cost. First, there are the hidden subsidies and, second, there are the negative external effects that damage the environment and people's health. Since antiquated power plants are exempt from the Clean Air Act, they may emit, without penalty, ten times as much pollution as even modern coalfired plants. This gives them a competitive edge over cleaner sources of energy. From 1992 to 1998, the amount of electricity generated from old coal-fired plants increased by almost 16 percent. These subsidies are perverse because the true costs from harm to the environment and people's health are omitted, giving the wrong pricing information to decision-makers. Investment in new technologies may be postponed by extending the life of an old fossil fuel plant that should have been closed years ago. Consequently, entrepreneurs are discouraged from investing 
in non-polluting, renewable energy projects because the rates of return on the capital investment are not high enough or quick enough. European countries have been experimenting with providing incentives for conservation in the tax structure, by reducing taxes on incomes and instituting new taxes on fossil fuels that reflect the ecological cost of producing greenhouse gas emissions (Fischlowitz-Roberts, 241-245).

The World Bank calculated that in China the environmental and health costs of air pollution due mainly to burning coal totaled approximately 7 percent of GDP in 1995. China reduced its coal subsidies from $\$ 750$ million in 1993 to $\$ 240$ million in 1995, and put a new tax on high sulfur coal. Consequently, China used 14 per cent less coal between 1996 and 2000. According to Lester Brown, China is also subsidizing the development of wind energy to further reduce its reliance on coal. China increased its wind generating capacity to 1,270 megawatts (MW) at the end of 2006. India, the world's fourth largest producer of wind energy $(4,430 \mathrm{MW})$, is a major producer of wind turbines. These two nations are providing important examples for other less developed countries seeking to industrialize. By adopting alternative clean energy fuels, they show the way to less dependence on fossil fuels leading to a cleaner and healthier life for its citizens.

\section{THE INCREASING POSSIBILITIES OF RENEWABLE ENERGY}

Wind power is preferable to fossil fuels because it is a renewable energy source that does not contribute to global warming. It is free of pollution. Wind can be found all over the planet and is inexhaustible. Once the initial costs of the turbine and installation are made, unlike coal and oil, wind arrives without any further cost, other than maintaining the machine. Unlike building a large power plant, wind turbines are modular and can be put together in a few months to make a wind farm to produce power equivalent to a conventional power station. Wind is available on all continents and is distributed widely in every country. Consequently reliance on wind energy reduces your dependence on foreign oil and other energy sources centrally located.

Cost-efficient technology to harness wind power has been developed over the last decade. Three European countries are responsible for making wind energy the world's fastest growing energy source. Denmark has been in the forefront of developing and using the new wind technology and gets 21 percent of its current electricity needs from wind turbines. When Denmark decided to undertake the development of wind power, the cost of producing electricity this way was much higher than that produced by fossil fuels. A distinguishing aspect of the Danish program is that 85 percent of capacity is owned by individuals or wind cooperatives. In less than a decade Germany became the world leader in installed capacity for wind-generated electricity, producing 20,622 megawatts. Three German states obtain more than 30 percent of their electricity from wind. Nationally, more than eight percent of Germany's electricity comes from wind. Spain's northern industrial province of Navarra is now producing over 55 percent of its electricity from wind. In eleven years world production of wind energy has increased fifteen times (from 4,800 megawatts in 1995 to 74,223 megawatts in 2006). Of this amount, the European Union member nations (EU) have 48,062 megawatts. In a major study for the EU, Wind Force 12 projects that the EU could easily produce $20 \%$ of its electricity from wind by 2020 . By then, this study forecasts that $12 \%$ of the world's electricity will be from wind power. (EWEA)

The examples of Denmark, Germany and Japan becoming world leaders in renewable energy demonstrate that the "impossible" can be done in a relatively short period of time. At the beginning of 1990s, Germany had virtually no renewable energy capacity. In 1997 Germany surpassed the United States to become the world's leading energy producer. It now has almost a third of total installed wind capacity. In addition it has become a global leader in solar photovoltaic (PV) generated power, second only to Japan. Consequently, Germany is well on its way to meeting its pledge of reducing carbon dioxides emissions 21 percent below its 1990 level by 2010. By 2025, Germany expects to get 25 percent of its electricity from wind energy.

Due to advances in technology since 1995, the cost of producing wind energy has been reduced considerably since the 1980s: from 38c a kilowatt-hour to 4c today. Some long-term contracts in the United States provide electricity from wind at $3 \mathrm{c}$ a kilowatt-hour. There is plenty of harnessable wind energy in the United States. In fact, three states-North Dakota, Kansas, and Texas could provide the wind energy to meet all the demand for electricity in the United States. 
As of January 2007, the United States had 11,603 megawatts (MW) of installed wind energy capacity (AWEA, 2007). The leading states are Texas with 2,768MW, California with 2,361 MW, Iowa with $936 \mathrm{MW}$, Minnesota with $895 \mathrm{MW}$, Washington with $818 \mathrm{MW}$, Oklahoma with 535MW and Oregon with 439MW. Thus, the United States with 11,603 MW is only slightly behind Spain with 11,615MW. But currently the United States is only generating $1 \%$ of its electricity from wind. One megawatt of wind generating capacity will satisfy the electricity needs of approximately 1000 people in an industrial society for one year.

\section{Solar Photovoltaic Technology}

Solar photovoltaic (PV) cells convert sunlight directly into electricity and are the world's fastest growing energy source. Over the past five years, the world market growth of PV has averaged 42 percent per year. In 2006 the global market for PV was approximately $\$ 12$ billion and $1700 \mathrm{MW}$ of solar PV was installed. Although the solar cell industry started in the United States and the United States had 44 percent of the market in 1996, its global market share had fallen below nine percent in 2005.

For most of the past decade, Japan has led the world in the production of solar PV, accounting for 48 percent of production in 2005. Despite having half the solar resource of California, Japan became the world leader because of strong government incentives, gradually declining rebates, net-metering, low-interest loans, and public education programs (Sawin, 29). These policies drove down system costs by more than 80 percent. Consequently, rooftop power became competitive with Japanese electricity prices. Japan has a national target of installing 4800MW of PV by 2010.

Germany has the largest market for solar PV in the world today. In 2005 Germany added 837 MW of new capacity. The market growth in Germany and other leading markets is due to long term policies that provide economic incentives to solar PV owners. Utilities have to buy the excess power at the retail price.

\section{PRACTICAL POLICY RECOMMENDATIONS}

For nations and regions still unsure how to move forward into the world of cleaner energy and low carbon emissions, the following policies have been successful in Germany and Japan:

1. German government required utility companies to buy all electricity produced by renewable energy in their region at 90 percent of retail price.

2. After careful research, the government established a payment tariff for each renewable energy source based on per kilowatt hour and the cost of producing that particular type of energy. Payments could be paid up to twenty years.

3. To make it easier to establish wind projects, the government encouraged each community to establish zones suitable for wind turbines.

4. To overcome opposition from electricity grid operators, the government required these operators to make the connection to the grid for new customers and to upgrade the wiring, where necessary.

5. Low interest loans to individuals or companies investing in renewable energy projects were made by banks and refinanced by the federal government.

6. Germany made a pledge to reduce its $\mathrm{CO} 2$ emissions (Sawin, Mainstreaming...p.27-32).

7. Reduce or remove all subsidies for carbon-based energies.

8. Establish a stable business investment climate for renewables by making long term commitments to potential investors.

9. Organize advisory agencies in various cities to raise awareness of these policies, grants, and subsidies and to provide education and training for would-be owners or investors (as in Britain).

Just as Germany was able to take advantage of its neighbor Denmark's experience of success with wind energy, so the United States can use Germany's experience to learn how to build a domestic energy supply that is nonpolluting, cost effective, secure, and homegrown. Without the leadership of important government leaders in promoting long term commitments to a sustainable energy future, it will be difficult to break the hold of large 
energy interests and corporations over the present energy system in America. Equally important is a public commitment to achieve a long term target. Nations that have succeeded in drastically reducing green house gases and making breakthroughs in renewable technology that are accepted by large numbers of citizens have made such commitments. At the state level, California's Governor Schwarzenegger has committed to reduce GHG emissions by 25 percent by 2020 and has launched a program to install one million solar PV systems on roofs in California by 2017. While this type of commitment may seem unrealistic, such a commitment provides a vision of the future that citizens can make a reality by taking advantage of the $\$ 3.2$ billion set aside for incentives to adopt the new technology.

\section{CONCLUSION}

The world has been on a collision course with its current reliance on fossil fuels for its main source of energy. Europe has already begun the long process of extricating itself from the harmful effects of carbon pollution. The United States has a long way to go to catch up with Denmark, Germany and Spain and to extricate ourselves from dependency on fossil fuels. Wind and other solar energies have the ability to produce energy in a clean and widely distributed manner. They can reduce our dependence on oil from the Middle East and reduce the dangers of global warming by making it feasible to close old coal fired power plants that cannot meet 1992 Clean Air Standards. By reducing perverse subsidies for fossil fuels and giving incentives to wind and other solar energy producers, we will be able to develop a sustainable energy future that will maintain the current quality of life for our children and grandchildren.

\section{BIBLIOGRAPHY}

1. American Wind Energy Association (AWEA) (2007). http://awea.org.

2. Ball, Jeffrey The Texas Wind Powers a Big Energy Gamble, Wall Street Journal, March 12, 2007.

3. Blowing Hot and Cold, The Economist, July 4, 2002.

4. Bottom-up Greenery, The Economist, March 18,2004.

5. $\quad$ British Wind Energy Association (BWEA) (2004), http://bwea.org.

6. Brown, Lester R. (2001). Eco-economy: Building an Economy for the Earth. New York: W.W. Norton \& Co.

7. Brown, Lester R. (2003). Plan B: Rescuing a Planet under Stress and a Civilization in Trouble. New York: W.W. Norton \& Co.

8. Cameron, Doug. Coal still powering ahead in U.S. Financial Times, February 27, 2007, 16

9. Clayton, Mark A more efficient U.S. Energy agency prods only a bit, Christian Science Monitor, October 24, 2006, 2.

10. Congressional Budget Office. Addressing the Uncertain Prospect of Climate Change, (2003, April, 25) www.cbo.gov/showdoc.cfm? index $=4181+$ sequence $=0$.

11. Degrees of difference (2004, April 29). The Economist.

12. Easton, Nina. California Dreamin' Interview with Arnold Schwarzenegger in Fortune, April 2,2007, 7274.

13. Engardo, Pete. Beyond the Green Corporations, BusinessWeek, January 29, 2007, 50-64.

14. European Renewable Energy Council (EREC) (2003). Renewable Energy Target for Europe 20\% by 2020."

15. European Renewable Energy Council (2004). Renewable Energy: The Solution to Climate Change.

16. European Wind Energy Association (EWEA) (2007). Wind Force 12, Brussels..

17. Fischlowitz-Roberts, Bernie (2002). Tax Shifting on the Rise, in Lester Brown (Ed.), Earth Policy Reader. New York: W. W. Norton.

18. Flannery, Tim. The Weather Makers: How Man is Changing the Climate and What it Means for life on Earth, Atlantic Monthly Press, 2005.

19. Ford, Peter. China Moves to Curb its Carbon Footprint,Christian Science Monitor, April 26, 2007, 1, 10.

20. Gunther, Marc. Green is Good: The Companies, Fortune, April 2, 2007, 44.

21. Harvey, Fiona. U.S. generates record year for wind turbines, Financial Times, February 27, 2007, 16. 
22. Knickerbocker, Brad. This Earth Day, a focus on Earth's Warming, Christian Science Monitor, April 20, 2007.

23. Mansfield, Duncan. Idled TVA reactor set to reopen, Commercial Appeal (Memphis), May 7, 2007, A1 and 3.

24. Mufson, Steven. California’s Thrifty Example, Washington Post National Weekly, February 26-March 4, 2007, 20.

25. Sawin, Janet (2003). Charting a New Energy Future. In State of the World 2003, New York: W.W. Norton \& Co., 85-109.

26. Sawin, Janet (2004) Mainstreaming Renewable Energy in the $21^{\text {st }}$ Century, Worldwatch Institute.

27. Tilting at windmills, The Economist. March 18, 2004.

28. United Kingdom Ministry of Trade and Industry (2003, February). Our Energy Future - creating a low carbon economy (Energy White Paper).

29. Velasquez-Manoff, Moises. Before regulation hits, a battle over how to build new coal plants, Christian Science Monitor, February 22, 2007, 13.

30. Worldwatch Institute.(2006) Vital Signs2006-2007: The Trends that are Shaping our Future, New York: W.W. Norton \& Co.

\section{NOTES}

